\title{
Methane potentials of the Swedish pulp and paper industry - A screening of wastewater effluents
}

Eva-Maria Ekstrand, Madeleine Larsson, Xu-Bin Truong, Lina Cardell, Ylva Borgstrom, Annika Björn, Jörgen Ejlertsson, Bo Svensson, Fredrik Nilsson and Anna Karlsson

\section{Linköping University Post Print}

\section{Tweet}

N.B.: When citing this work, cite the original article.

Original Publication:

Eva-Maria Ekstrand, Madeleine Larsson, Xu-Bin Truong, Lina Cardell, Ylva Borgstrom, Annika Björn, Jörgen Ejlertsson, Bo Svensson, Fredrik Nilsson and Anna Karlsson, Methane potentials of the Swedish pulp and paper industry - A screening of wastewater effluents, 2013, Applied Energy, (112), 507-517.

http://dx.doi.org/10.1016/j.apenergy.2012.12.072

Copyright: Elsevier http://www.elsevier.com/

Postprint available at: Linköping University Electronic Press

http://urn.kb.se/resolve?urn=urn:nbn:se:liu:diva-104129 


\section{THE METHANE POTENTIAL OF THE SWEDISH PULP AND PAPER INDUSTRY - A} SCREENING OF WASTEWATER EFFLUENTS

Eva-Maria Ekstrand ${ }^{1 \dagger}$, Madeleine Larsson ${ }^{1 \dagger *}$, Xu-Bin Truong ${ }^{2}$, Lina Cardell ${ }^{2}$, Ylva Borgström $^{3}$, Annika Björn ${ }^{1}$, Jörgen Ejlertsson ${ }^{1,2}$, Bo H. Svensson ${ }^{1}$, Fredrik Nilsson ${ }^{3}$, Anna Karlsson $^{2}$

${ }^{1}$ Dep. of Thematic Studies, Water and Environment, Linköping University, 58183 Linköping, Sweden

${ }^{2}$ Scandinavian Biogas Fuels AB, Holländargatan 21A, 11160 Stockholm, Sweden

${ }^{3}$ Pöyry Sweden AB, Hotellgatan 5, 60222 Norrköping; Sweden

*Corresponding author Phone: +46706255106 , Fax: +4613133630

$\dagger$ Indicated authors contributed equally to this work

\section{ABSTRACT}

With the final aim of reducing the energy consumption and increase the methane production at Swedish pulp and paper mills, the methane potential of 62 wastewater effluents from ten processes at seven pulp and/or paper mills (A-G) was determined in anaerobic batch digestion assays. This mapping is a first step towards an energy efficient and more sustainable utilization of the effluents by anaerobic digestion, and will be followed up by tests in lab-scale and pilot-scale reactors. Five of the mills produce kraft pulp (KP), one thermo-mechanical pulp (TMP), two chemical thermo-mechanical pulp (CTMP) and two neutral sulfite semichemical (NSSC) pulp. Both elemental and total chlorine free (ECF and TCF, respectively) bleaching processes were included. The effluents included material from wood rooms, cooking and oxygen delignification, bleaching (often both acid- and alkali effluents), drying and paper/board machinery as well as total effluents before and after sedimentation.

The results from the screening showed a large variation in methane yields (percent of theoretical methane potential assuming $940 \mathrm{NmL} \mathrm{CH}_{4}$ per $\mathrm{g} \mathrm{TOC}$ ) among the effluents. For the KP-mills, methane yields above 50\% were obtained for the cooking effluents from mills D and $\mathrm{F}$, paper machine wastewater from mill $\mathrm{D}$, condensate streams from mills $\mathrm{B}, \mathrm{E}$ and $\mathrm{F}$ and the composite pre-sedimentation effluent from mill D. The acidic ECF-effluents were shown to be the most toxic to the AD-flora and also seemed to have a negative effect on the yields of composite effluents downstream while three of the alkaline ECF-bleaching effluents gave positive methane yields. ECF bleaching streams gave higher methane yields when hardwood was processed. All TCF-bleaching effluents at the KP mills gave similar degradation patterns with final yields of $10-15 \%$ of the theoretical methane potential for four of the five effluents. The composite effluents from the two NSSC-processes gave methane yields of $60 \%$ of the theoretical potential.

The TMP mill (A) gave the best average yield with all 6 effluents ranging $40-65 \%$ of the theoretical potential. The three samples from the CTMP process at mill B showed potentials around $40 \%$ while three of the six effluents at mill G (CTMP) yielded 45-50\%. 
Keywords: biogas, anaerobic digestion, kraft pulp, chemical thermo-mechanical pulp, neutral sulfite semi-chemical pulp, bleaching

\section{INTRODUCTION}

Large volumes of wastewater are produced within the pulp and paper industry worldwide. Much of this is today treated in activated sludge processes. The resulting sludge is often dewatered and incinerated or, treated for a fee and used as e.g. filling material [1]. This treatment can incur a cost for the mills at the same time as the potential energy and nutrient content of the effluents is not considered. A way of exploring these resources can be anaerobic digestion (AD), which can have several benefits compared to aerobic techniques. One option is to treat the effluents directly in an upflow anaerobic sludge blanket (UASB) reactor, followed by an activated sludge bed for final treatment of the remaining organic matter. The residues from the activated sludge process (with or without pre-treatment in an UASB-system) can also be used as a substrate in a completely stirred tank reactor (CSTR). Another option is to only use a CSTR-system with sludge recirculation, to allow for the low retention time necessary in systems with high volumetric loading rates. In either case the advantages of $\mathrm{AD}$ include reduction of the sludge volume by $30-70 \%$ [2] and the production of methane as an energy carrier. In addition, nutrients that are released during AD can be used in the activated sludge basins, thereby reducing the need for commercial nitrogen and phosphorus additions. Hence, anaerobic treatment of effluents from pulp and paper processing can transform the organic matter to methane for the production of vehicle fuel or electricity at the same time as the nutrients in the anaerobic digestate can be used as fertilizer for arable land or forests. This approach will thus reduce both the power consumption and the need of commercial nutrients for the aerobic biological process, since less aeration and external nutrient additions are needed when combined with anaerobic treatment.

Papermaking is initiated by pulping, where mechanical or chemical techniques are used. In mechanical processing the fibers are separated in refiners and the pulp produced contains all wood constituents (eg. cellulose, lignin and hemicellulose) with only moderate chemical modifications. Thermo-mechanical pulping (TMP) involves pressurized steaming of the wood linked to the refining and is often complemented with a chemical step resulting in the chemical thermo-mechanical pulping process (CTMP; reviewed by [3]). Hydrogen sulfite $\left(\mathrm{HSO}_{3}{ }^{-}\right)$is the main chemical used in the CTMP process. Bleaching of TMP and CTMP pulp is primarily achieved using hydrogen peroxide $\left(\mathrm{H}_{2} \mathrm{O}_{2}\right)$.

In the kraft pulp (KP) process, wood chips are cooked with white liquor where sodium hydroxide $(\mathrm{NaOH})$ and sodium sulfide $\left(\mathrm{Na}_{2} \mathrm{~S}\right)$ are the active components. However, sodium carbonate $\left(\mathrm{Na}_{2} \mathrm{CO}_{3}\right)$, sodium sulfate $\left(\mathrm{Na}_{2} \mathrm{SO}_{4}\right)$, sodium sulfite $\left(\mathrm{Na}_{2} \mathrm{SO}_{3}\right)$ and sodium thiosulfate $\left(\mathrm{Na}_{2} \mathrm{~S}_{2} \mathrm{O}_{3}\right)$ are also present in the liquor. Part of the lignin and hemicelluloses are de-polymerized and dissolved during this cooking process, leaving about $50 \%$ of the dry weight of the wood chips in the solid pulp [3]. In the neutral sulfite semi-chemical (NSSC) process, a mix of $\mathrm{Na}_{2} \mathrm{SO}_{3}$ and $\mathrm{NaHCO}_{3}$ is used to dissolve the lignin. The pulp obtained is washed and often bleached. In Sweden, bleaching is achieved by elemental chlorine free (ECF) or total chlorine free (TCF) processes. In ECF-bleaching $\mathrm{ClO}_{2}$ and $\mathrm{H}_{2} \mathrm{SO}_{4}$ are used in an acidic step (pH 2-3) and $\mathrm{NaOH}$ (often in combination with $\mathrm{O}_{2}(\mathrm{O})$ and hydrogen peroxide $(\mathrm{P})$ ) 
in an alkaline step $(\mathrm{pH}>10)$, while in TCF bleaching acid $\left(\mathrm{H}_{2} \mathrm{SO}_{4} ; \mathrm{A}\right)$, ozone $(\mathrm{Z}), \mathrm{O}$, chelating agents (Q) and/or P steps are combined in different ways. The type of process (TMP, CTMP, KP or NSSC), the raw material and the bleaching sequence all affect the composition of the wastewaters obtained at the mills and, thus, also their potentials as substrates for AD.

Due to the great differences in effluent characteristics, AD has been utilized with various degree of efficiency on effluents from the pulp- and papermaking industry. For bleached/unbleached TMP and CTMP effluents, AD has been successfully implemented in full scale, as well as for NSSC and kraft/sulphite mill condensates [4-6]. However, with increasing concentrations of substances such as tannins, resin acids, wood extractives or lignin in the effluents, the microorganisms of the $\mathrm{AD}$ process can become inhibited. Wastewaters that are known to be toxic to methanogens include wood-room effluents, composite CTMP-wastewaters, spent liquors from chemical pulping and bleaching effluents (reviewed in [7-8]).

The results regarding TOC- (total organic carbon) and/or COD- (chemical oxygen demand) reductions from $\mathrm{AD}$-treatments are not always consistent and in many cases hard to compare as the composition of studied effluents are highly dependent on the mill's pulping process, internal water circulation, amount of supplied fresh water and the type of wood used as raw material. All these factors will affect the type of chemicals released with the wastewater, as well as the concentration of TOC/COD and its organic composition (reviewed in [9]). In addition, most of the work published so far focuses mainly on toxicity reduction of pulp and paper industry effluents [10-13], often not considering the large biogas potential in many of these often TOC/COD dense effluents.

As a first step towards a higher degree of implementation of $\mathrm{AD}$, with the final aim of producing methane and at the same time save energy by decreasing the need of aerobic wastewater treatment at Swedish pulp and paper mills, we here report on a survey over methane potentials of 62 wastewater effluents from 10 processes at seven pulp and/or paper mills. The investigation is part of an effort towards a more extended implementation of AD at Swedish pulp and paper mills. The potentials were determined by anaerobic incubation of effluent samples in batch tests. Five of the sampled mills produce KP, one TMP, two CTMP and two NSSC pulp. . The effluents sampled included effluents from wood room, cooking and oxygen delignification, bleaching (often both acidic- and alkaline effluents), drying- and paper/board machinery as well as total wastewater effluents before and after sedimentation.

\section{MATERIAL AND METHODS}

\subsection{Sampling of pulp and paper mills}

Wastewater effluents from ten pulp and paper processes at seven Swedish mills were sampled, in total 62 samples were obtained. One TMP, two CTMP, two NSSC and five KP (three with ECF and two with TCF bleaching) processes were included (Table 1). Four of the five KP-mills are combined pulp and paper mills, two of these produce liquid packaging board and two produce paper. The fifth KP-mill produces market pulp. The TMP- and CTMP mills use $\mathrm{P}$ for bleaching. The sampled streams are listed in Table 2. All samples were collected in two litre plastic bottles and immediately transported to the lab to investigate experimental methane yields 
by methane potential batch tests (described below). The tests were in all cases initiated within $30 \mathrm{~h}$ of sampling. The $\mathrm{pH}$, total COD and total TOC of the sampled effluents were measured before incubation.

Table 1 Description of the processes for sampled mills at the time of sampling. hw = hardwood; sw $=$ softwood; rec. paper $=$ recycled paper; Bleaching steps: $A=$ acid; $D=\mathrm{ClO}_{2}, E=$ alkaline; $O$ = oxygen $\mathrm{P}=$ hydrogen peroxide; $\mathrm{Q}=$ chelating agents; $\mathrm{Z}=$ ozone

\begin{tabular}{llll}
\hline Mill & Process & Raw material & Bleaching \\
\hline A & TMP & sw (spruce) & P ( 2/3 of the pulp) \\
B & CTMP & sw (spruce) & P \\
B & Kraft & sw & $\begin{array}{l}\text { OO aQ O(P)AZq } \\
\text { PO }\end{array}$ \\
C & NSSC & hw and rec. & - \\
C & Kraft & sw or hw & D (EOP) D P \\
D & NSSC & hw & - \\
D & Kraft 1 & hw & D EP D \\
D & Kraft 2 & sw & D (EOP) D EP D \\
E & Kraft & hw or sw & OO QQ Po Po \\
F & Kraft & sw (pine) & D0 E0 D1 D2 \\
G & CTMP & sw & -
\end{tabular}


Table 2 Data of sampled pulp and paper mill waste effluents. Final methane yields expressed in \% of the theoretical potential $(940 \mathrm{NmL} / \mathrm{g} \mathrm{TOC})$ : $\leq 20 \%$; $=20-30 \%=30-40 \%$; $=40-50 \%$; $\geq 50 \%$. CTMP=chemical thermo-mechanical pulp; DM=drying machines; ECF=elemental chlorine free; NSSC=neutral sulfite semi-chemical; PM=paper machines; pre-sed=presedimentation, $\mathrm{P}=$ =hydrogen peroxide; TCF=total chlorine free, TMP=thermo-mechanical pulp

\begin{tabular}{|c|c|c|c|c|c|c|c|}
\hline Mill & $\begin{array}{l}\text { Mill } \\
\text { A }\end{array}$ & Mill B & Mill C & Mill D & Mill E & Mill F & $\begin{array}{l}\text { Mill } \\
G^{1}\end{array}$ \\
\hline Process & TMP & $\begin{array}{l}\text { CTMP } \\
\text { Kraft }\end{array}$ & $\begin{array}{l}\text { NSSC } \\
\text { Kraft }\end{array}$ & $\begin{array}{l}\text { NSSC } \\
\text { Kraft }\end{array}$ & Kraft & Kraft & CTMP \\
\hline Sampled effluents & 6 & 10 & 11 & 10 & 7 & 10 & 6 \\
\hline Wood room & $\mathrm{A} 2$ & B1 & C9 & D1 & - & F1 & - \\
\hline TMP/CTMP; Pulping; & $\mathrm{A} 5$ & - & - & - & - & - & G2 \\
\hline Kraft pulping & - & - & C14 C15 & D4 & E12 & E3 & - \\
\hline $\begin{array}{l}\text { Kraft; Acid bleach ; } \\
\text { ECF }\end{array}$ & - & - & $\frac{\mathrm{C} 2 \mathrm{~S}}{\mathrm{C} 2 \mathrm{H}}$ & D7 D9 & - & F4 & - \\
\hline $\begin{array}{l}\text { Kraft; Alkali bleach; } \\
\text { ECF }\end{array}$ & - & - & $\frac{\mathrm{C} 3 \mathrm{~S}}{\mathrm{C} 3 \mathrm{H}}$ & D8 D10 & - & - & - \\
\hline $\begin{array}{l}\text { Kraft; Total bleach; } \\
\text { ECF }\end{array}$ & - & - & $\mathrm{C} 6$ & - & - & F6 & - \\
\hline Kraft; Bleach; TCF & - & $\mathrm{B} 3 \mathrm{~B} 4$ & - & - & E6 E7 & - & - \\
\hline TMP/CTMP Bleach; P & A41 & B7 B9 & - & - & - & - & G \\
\hline Condensate effluents & - & $\mathrm{B} 12$ & - & - & E9 & F20 & - \\
\hline PM/DM white waters & A9 & B5 & C1 & D11 & - & - & - \\
\hline NSSC composite efflu. & - & - & C10 & D3 & - & - & - \\
\hline Before pre-sed. & & $\mathrm{B} 10$ & C7 & D6 & E15 & F10 & G7 \\
\hline After pre-sed. & A13 & $\mathrm{B} 11$ & C8 C11 & $\begin{array}{l}\text { D13 } \\
\text { D14 }\end{array}$ & E16 & $\frac{F 15 F}{F 17}$ & \\
\hline
\end{tabular}




\subsection{Batch experiments}

The methane potential of the 62 effluents (Table 2) was evaluated in batch tests, using 320 $\mathrm{mL}$ serum bottles, sealed with rubber stoppers and aluminum screw caps. $137 \mathrm{~g}$ of effluent, 10 $\mathrm{mL}$ inoculum (reactor material from the municipal wastewater treatment plant in Linköping, Sweden) and salts $\left(\mathrm{NH}_{4} \mathrm{Cl}, 0.3 \mathrm{~g} \mathrm{~L}^{-1} ; \mathrm{NaCl}, 0.3 \mathrm{~g} \mathrm{~L}^{-1} ; \mathrm{CaCl}_{2} * 2 \mathrm{H}_{2} \mathrm{O}, 0.1 \mathrm{~g} \mathrm{~L}^{-1}\right.$ and $\mathrm{MgCl}_{2} * 6 \mathrm{H}_{2} \mathrm{O}, 0.1 \mathrm{~g} \mathrm{~L}^{-1}$ ) were added while flushing with $\mathrm{N}_{2}$. Each bottle had a final liquid volume of $150 \mathrm{~mL}$. After sealing, the headspace gas in the bottles was exchanged for $\mathrm{N}_{2}: \mathrm{CO}_{2}$ (80:20) and $0.5 \mathrm{~mL} 100 \mathrm{mM} \mathrm{Na}_{2} \mathrm{~S}$ was added to each bottle. Two references were included in each set of experiments: inoculum controls without added substrate and positive controls, to which $0.1 \mathrm{~g}$ cellulose (Whatman filter paper No 3) was added as substrate. All tests were performed in triplicate and the bottles were incubated in the dark at $37^{\circ} \mathrm{C}$ for a maximum of 80 days. If needed, the $\mathrm{pH}$ of the effluents was adjusted to between 7 and 8 before distribution to the serum bottles. A solution of either $\mathrm{NaOH}$ or $\mathrm{HCl}$ with the concentration of $1 \mathrm{~mol} \mathrm{~L}^{-1}$ was used for the $\mathrm{pH}$-adjustments.

\subsection{Analyzed parameters}

The $\mathrm{pH}$ of the effluents was determined according to [14] using a $\mathrm{pH}$ electrode (Inolab $\mathrm{pH}$ 730,WTW, Germany). For COD and TOC, kits from Hach-Lange (LCK114; LCK514; LCK014 and LCK386; LCK387, respectively) were used according to the manufacturer's instructions.

The gas production in each bottle was determined by measuring the pressure at each sampling occasion, using a Testo 312-3 Precision manometer (Testo Inc., USA). Samples for methane analysis were taken from the gas phase before adjusting the pressure in each bottle to ambient. The methane content of the headspace gas was determined by gas chromatography with a flame ionization detection (GC-FID; [15]). Gas was sampled at $37^{\circ} \mathrm{C}$ and the gas released was accounted for when calculating the methane yields. The measurements were normally performed on day $1,3,7, \sim 14, \sim 20, \sim 30$ and $\sim 45$ from incubation start. All gas volumes presented have been normalized to 1 atm pressure and $273 \mathrm{~K}$ and are expressed as "normalized $\mathrm{mL}$ " $(\mathrm{NmL})$. The data presented in the graphs are mean values of triplicates \pm standard deviation (SD). For each effluent, supplementary data on $\mathrm{pH}, \mathrm{TOC}, \mathrm{COD}, \mathrm{COD}$ $\mathrm{TOC}^{-1}$ and methane yield per g TOC are given in Appendix A (tables A.1-A.11).

\subsection{Theoretical $\mathrm{CH}_{4}$-yield per TOC $\left(\mathrm{NmL} \mathrm{g}^{-1}\right)$}

For the methane yield calculations, the TOC content was assumed to be $100 \%$ carbohydrates. Complete anaerobic degradation of carbohydrates gives a 1:1 ratio between $\mathrm{CH}_{4}$ and $\mathrm{CO}_{2}$. This means that $0.042 \mathrm{~mol} \mathrm{CH}_{4}$ is produced per $\mathrm{g}$ of TOC, which corresponds

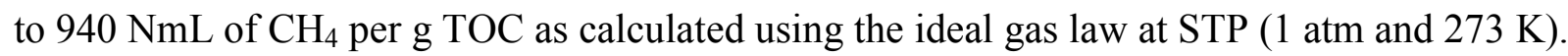

\subsection{Statistical/Chemometrical analyses}

Principal component analysis (PCA) was applied on data from all effluents (bi-plot not shown). Due to dominance in the bi-plot by B1 and B12, PCA was also applied for the dataset excluding B1 and B12 (Figure 2). The software used for the analysis was developed in-house 
in MATLAB ${ }^{\circledR}$ 7.3.0. Included variables were TOC, COD TOC $^{-1}, \mathrm{pH}$ and methane yield per $\mathrm{g}$ added TOC. Before performing the PCA the variables were mean-centered and scaled to unit variance.

\section{RESULTS AND DISCUSSION}

The results from the methane potential batch tests of the 62 samples are below categorized according to origin of each effluent. The following groups of effluents are represented: wood room, thermo-mechanical pulp processing, kraft pulp cooking, ECF pulp bleaching, TCF pulp bleaching, condensate effluents, paper making, NSSC-process effluents and total wastewater outlets before and after sedimentation. Table 2 gives an overview of the sampled effluents.

\subsection{Wood room effluents}

The five samples taken from wood rooms showed large variations in TOC $\left(0.2-7.7 \mathrm{~g} \mathrm{~L}^{-1}\right)$. The $\mathrm{pH}$ ranged 4.6-6.6 and the COD TOC ${ }^{-1} 3.2-3.8$ (Table A.1). The variations in TOC are likely linked to the extent of dilution (i.e. differences in the amount of water consumed and in the extent of recirculation within the system), to the raw material and the debarking method used.

The highest methane yield was obtained from A2 (Figure 1A), corresponding to $40 \%$ of the theoretical methane potential. D1, C9 and F1 gave rise to yields of $20-30 \%$ while the incubation of the sample from the wood room effluent at mill B (B1) inhibited the methane formation compared to the inoculum control. B1 was also by far the most TOC dense effluent ( $7.7 \mathrm{~g} \mathrm{~L}^{-1}$ ), with almost four times the TOC concentration in the sample from mill $\mathrm{C}$ that showed the second highest level $\left(2.0 \mathrm{~g} \mathrm{~L}^{-1}\right.$; Table A.1). C9 had a poor initial methane production compared to A2, D1 and F1 with methane yields below those registered in the controls until day 7. Thereafter the yields increased in two steps, i.e. between day 7 and 13 and later between day 45 and 69 (Figure 1A). The progression of methane formation from C9 indicates a late hydrolysis of the available TOC in this effluent. This may be the result of an adaptation by the microorganisms to initially inhibiting compounds or possibly a degradation of inhibiting compounds.

The methane formation observed for wood room effluents from mill A, D and F indicates that TOC originating from wood room treatments is not inhibiting to anaerobic microorganisms at levels around or below $1 \mathrm{~g}^{\text {TOC L}}{ }^{-1}$ (corresponding to $\sim 3.6 \mathrm{~g} \mathrm{COD} \mathrm{L}^{-1}$ ). Earlier reports give 50\% inhibiting concentration (IC50\%) values for methanogens of 0.9-1.9 $\mathrm{g} \mathrm{COD} \mathrm{L}^{-1}$ for wood room effluents (reviewed by [8]). The presence of resin acids, long chain fatty acids, volatile terpenes and tannins are often used as explanations for the observed inhibiting effects [7-8]. 

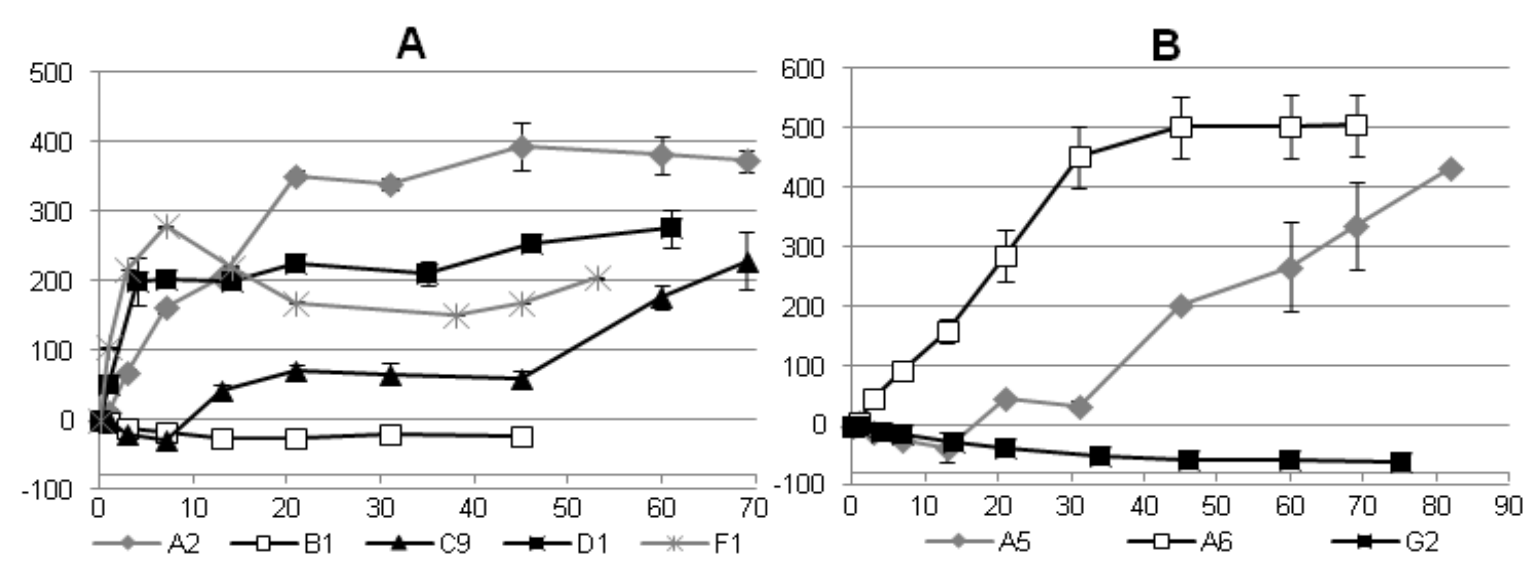

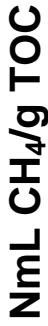
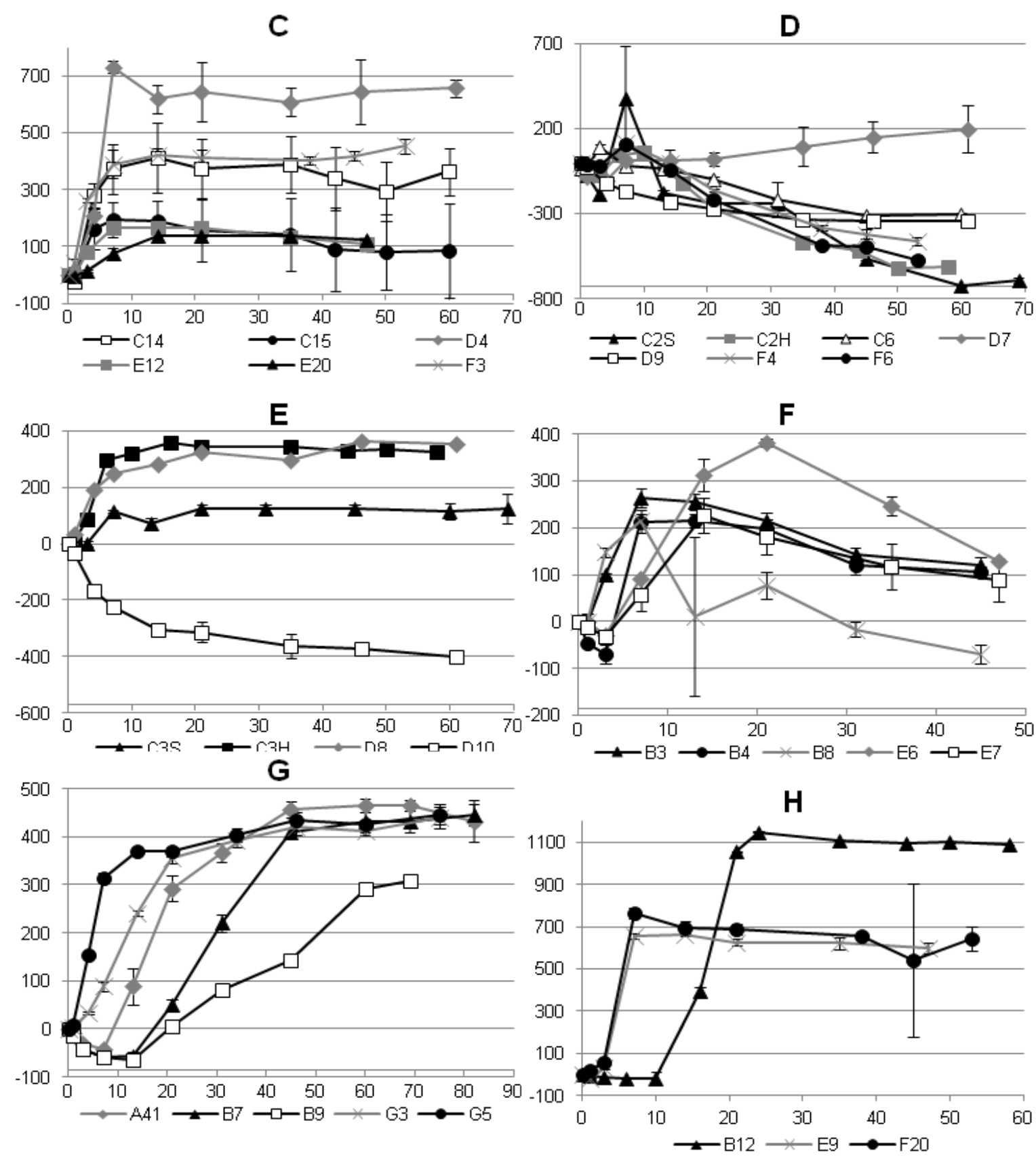

Time (days) 

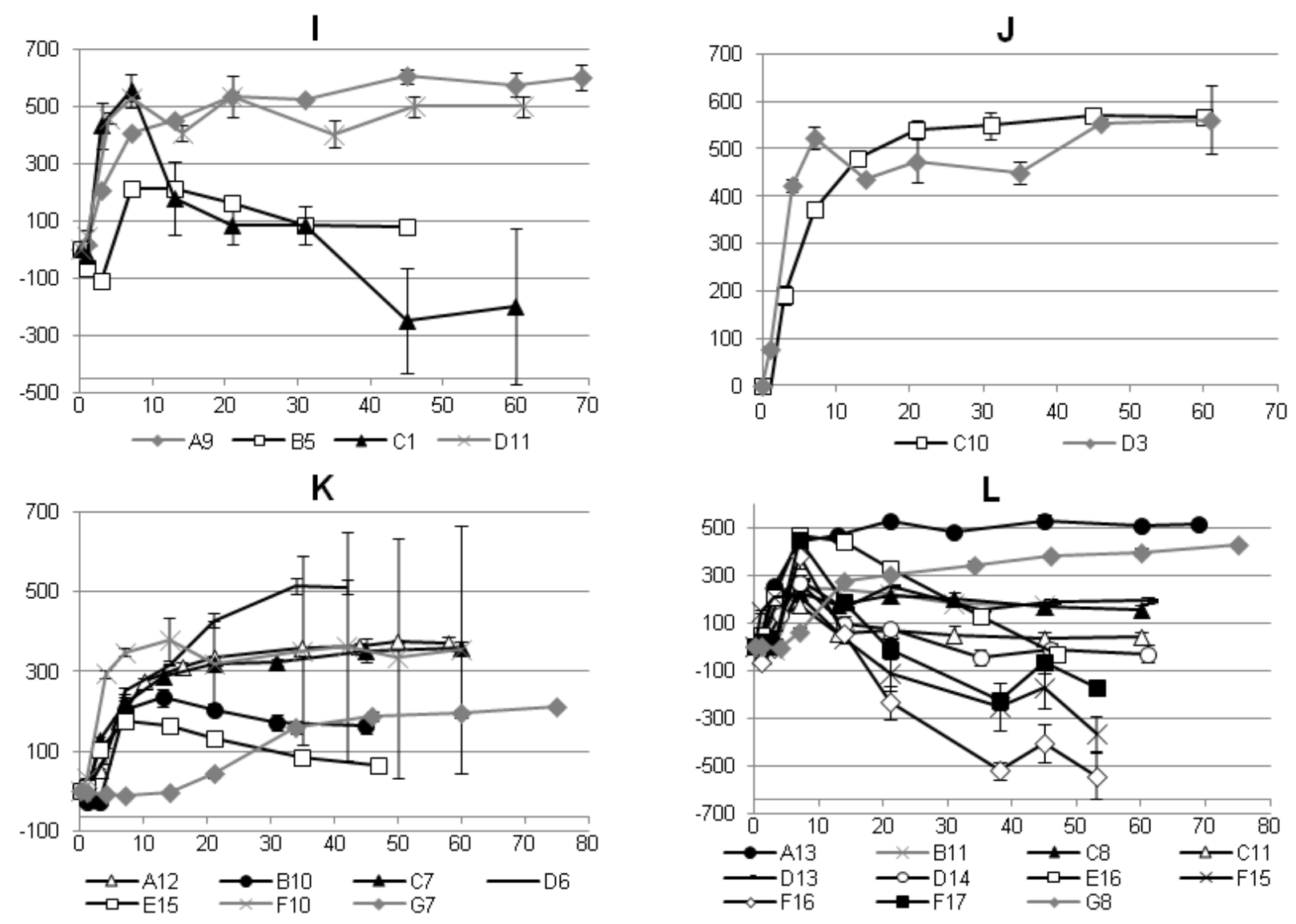
Figure 1 Accumulated methane production ( $\mathrm{NmL} / \mathrm{g} \mathrm{TOC}$; mean of triplicates with $\mathrm{SD}$ ) over time (days). $A=$ wood room effluents; $B=$ thermo-mechanical pulp processing effluents; $C=k$ raft pulp cooking effluents; $D=$ effluents from the $D$-step in kraft ECF pulp bleaching and total effluents from kraft ECF pulp bleaching; $E=$ =ffluents from the EOP-step in kraft ECF pulp bleaching; $F=T C F$ Pulp bleaching effluents; $\mathrm{G}=$ mechanical pulp bleaching effluents; $\mathrm{H}=$ condensates; I=paper making effluents; J=NSSC effluents; $K=$ before pre-sedimentation; $L=a f t e r$ pre-sedimentation.

\subsection{Thermo-mechanical pulp processing effluents}

Three of the samples taken from the TMP/CTMP mills were linked to the pulping process (Table 2), in all cases softwood was used in the production (Table 1). TOC of these effluents ranged between 1.5 and $2.9 \mathrm{~g}^{\text {TOC L }}{ }^{-1}$ with $\mathrm{COD} \mathrm{TOC}^{-1}$ between 3.5 and 4.0 and $\mathrm{pH}$ values from 4.4 to 8.5 (Table A.2). The highest methane yield was obtained in incubations with A6 (TMP-white water), where $54 \%$ of the theoretical potential was obtained. Also A5 (rejected screening effluent) showed a relatively high yield (45\%, Figure 1B) but with a longer lag phase/inhibited period than A6. This indicates differences in TOC-composition of A5 and A6 although representing the same process and with similar TOC-concentrations (Table A.2). No leveling off was seen for A5 at termination of the experiment, thus, the total yield for this effluent is likely underestimated (Table A.2). The lowest methane yield was obtained from effluent G2 (press filtrate after steaming) that gave a final yield below the production of the inoculum controls (Figure 1B and Table A.2).

These results imply higher methane yields for effluents from TMP compared to CTMP processes, which may be linked to the chemical additions in the CTMP production. Such an assumption is also supported by results reviewed by [8], that lists the IC50\% of CTMP effluents to 1.5-8.2 $\mathrm{g} \mathrm{COD} \mathrm{L}^{-1}$ compared to 11.5-13.7 $\mathrm{g} \mathrm{COD} \mathrm{L}^{-1}$ for TMP-waters. Effluents A5 and A6 (TMP) of this study contained $6.0 \mathrm{~g} \mathrm{COD} \mathrm{L}^{-1}$ and effluent $\mathrm{G} 210 \mathrm{~g} \mathrm{COD} \mathrm{L}^{-1}$ respectively (Table A.2).

\subsection{Kraft pulp cooking effluents}

Six samples were categorized as pulp-cooking effluents, containing wastewater from KP cooking, washing and oxygen delignification. However, the effluents E12 and F3 also contain wastewater from the alkaline bleaching step at the respective mill. The TOC of C14, C15, D4, $\mathrm{E} 12, \mathrm{E} 20$ and $\mathrm{F} 3$ was $0.2,0.2,0.2,0.5,0.8$ and $0.3 \mathrm{~g} \mathrm{~L}^{-1}$, respectively. COD TOC ${ }^{-1}$ ranged 2.9-4.1 and $\mathrm{pH}$-values were between 8.9 and 11.6 (Table A.3).

The highest yields were obtained for streams C14, D4 and F3 with $40 \%, 70 \%$ and $50 \%$ of the theoretical methane potential, respectively (Figure 1C). All three effluents originate from processing of softwood. Effluents C15 and E20 had yields of only about 10\% of the theoretical potential. E20 contains cooking effluents from a hardwood process line producing bleached pulp, while C15 is obtained from a production line producing unbleached softwood pulp.

The methane production mainly occurred during the first incubation week for all six cooking effluents although the final yields differed (Table A.3). This result imply that the TOC obtained from the kraft pulping and oxygen delignification steps contains more easily degradable organic matter, e.g. fragments from the depolymerization of lignin and hemicelluloses than the effluents from TMP/CTMP refining processes. The differences in yields between C14, D4 and F3 compared to C15, E12 and E20 is likely not linked to TOC 
concentration as the final yield in $\mathrm{C} 14$ was shown not to be affected by TOC-concentration in the range 0.2-0.8 $\mathrm{g} \mathrm{L}^{-1}$ (data not shown). It should also be noted that the SD is very large for C15.

D4 and F3 had the highest COD to TOC ratios of the six (3.9 and 4.1 for D4 and F3, respectively; Table A.3) which implies a higher content of more reduced carbon molecules (e.g. long chain fatty acids and methanol). Methane yields were also higher for D4 and F3 when calculated on added g COD (50 and 30\% respectively; data not shown) compared to on TOC (Table A.3).

Previous studies on AD of kraft pulping effluents show varying results. By treating synthetic black liquor using a lab-scale UASB, a methane yield of $18 \%$ has been reported by Kortekaas et al. [16]. It should however been noticed that the COD concentration was as high as $12 \mathrm{~g} \mathrm{~L}^{-1}$ in the Kortekaas study, thus the low yield could, at least in part, be caused by the high concentrations of inhibiting substances. In a study by Sierra-Alvarez, an average methane yield of $38 \%$ was achieved when treating black liquor with a lab-scale UASB, at a COD concentration of $2.6 \mathrm{~g} \mathrm{~L}^{-1}$. The data reported in [17] is still higher than several of the effluents included in this study (methane yields of 50\% for D4, 30\% for C14 and F3, and around $10 \%$ for $\mathrm{C} 15, \mathrm{E} 12$ and E20). Our lower yields might be due to the different methods used (UASB vs. batch), where the continuous treatment in a UASB could potentially lead to acclimatization of the microorganisms to the inhibiting substances of the pulping effluent.

\subsection{Kraft pulp bleaching effluents}

\subsubsection{ECF pulp bleaching}

Of the five effluents from acidic ECF bleaching steps, four gave negative methane yields compared to the inoculum controls while D7 showed a positive final methane yield (Figure 1D). The TOC values of the acidic effluents ranged 0.2-0.7 $\mathrm{g} \mathrm{L}^{-1}, \mathrm{COD}^{\mathrm{TOC}}{ }^{-1}$ was between 2.3-2.6 and the $\mathrm{pH}$ ranged 2.4-3.6 (Table A.4).

Three of the samples from the alkaline bleaching steps gave positive methane yields (C3S at $\sim 15 \%, \mathrm{C} 3 \mathrm{H}$ at $\sim 35 \%$ and $\mathrm{D} 8$ at $\sim 40 \%$ of the theoretical potential; Figure 1E). D10 was shown to have an inhibitory effect on AD (Figure 1E). D8 contains effluent from an EP sequence D10 effluent from an EOP sequence, while $\mathrm{C} 3 \mathrm{~S}$ and $\mathrm{C} 3 \mathrm{H}$ were sampled at different times from an EOP P sequence when softwood respective hardwood pulp was processed (Table 1). The TOC to COD ratios of the alkaline bleaching effluents were 2.3-2.7 and $\mathrm{pH} 10.8-11.6$ (Table A.4). The reason for the inhibition of the D10 incubations is not known but is likely due to a carryover of inhibiting substances from the D-steps

The composite bleaching effluents $\mathrm{C} 6$ and F6 $\left(0.5 \mathrm{~g}\right.$ and $\left.0.2 \mathrm{~g} \mathrm{TOC} \mathrm{L}^{-1}\right)$ inhibited methane production (Figure 1D). The COD TOC ${ }^{-1}$ of C6 and F6 were 2.1 and 2.5 and the $\mathrm{pH} 5.0$ and 2.9 respectively; Table A.4).

The highest yields from the ECF-bleaching effluents were obtained from the acid (D7) and alkaline (D8) bleaching streams of kraft process 1 (Table 1) at mill D and from the alkaline effluent $\mathrm{C} 3 \mathrm{H}$. The reason could be that both the process 1 effluents (D7 and D8) and $\mathrm{C} 3 \mathrm{H}$ processed hardwood. When the same alkaline bleaching effluent was sampled during production of softwood pulp (C3S), a much lower methane yield was achieved. The higher yields for the hardwood based alkaline effluents is in agreement with previous studies from 
sulphite pulping wastewater ([18]) and can likely be explained by the differences in chemical composition between hardwood and softwood. Hardwood have been reported to be more easily fractionated then softwood (reviewed by Janga et al. [19]) which might mean that more low molecular, degradable TOC is available in hardwood effluents. The higher lignin and resin acids content of softwood might also affect the degradability of softwood effluents in a negative way. Kostamo et al [20] showed that wastewater from a mill treating both hardwood and softwood contained less resin acids than mills treating only softwood, which is further supported by [21], where it is described that the extractives of softwood are more easily dissolved from the pulp during cooking due to formation of micelles. More research is however needed to explain the observed differences. The acidic hardwood effluent $\mathrm{C} 2 \mathrm{H}$ was inhibiting the methane production while the corresponding effluent at mill D (D7) gave a positive yield. This difference might be explained by the fact that mill $\mathrm{D}$ uses fresh-water in kraft process 1 , whereas mill $\mathrm{C}$ re-circulates the water within the bleaching process. This result implies that the methane potential of acid bleaching effluents are more linked to the bleaching chemicals used, while the methane potential of the alkaline bleaching steps are at least partly linked to the raw material processed. This is also supported by the fact that the total bleaching outlet from mill $\mathrm{C}$ inhibited the methane production, showing that the inhibiting compounds from the acidic bleaching step had an influence on the composite bleaching effluent at this mill. For mill F, the composite bleaching effluent mainly contain the acidic effluent mixed with wastewater from the chlorine dioxide production process, which may explain the stronger inhibiting effect of F6 compared to $\mathrm{C} 6$ that combines the acidic and alkaline effluents. That the acidic D-effluents (Figure 1D) were the most toxic can be due to the formation of chlorinated compounds in the treatment with $\mathrm{ClO}_{2}$ or to residual $\mathrm{ClO}_{2} / \mathrm{Cl}_{2}$. It should however also be noted that the toxicity of D-effluents have earlier been indicated to be, at least partly, associated with non-chlorinated organic compounds [22], possibly resin acids (reviewed by Rintala and Puhakka [9]).

\subsubsection{TCF pulp bleaching}

Five samples were taken from the two KP-mills using TCF-bleaching. B3 is a wastewater from the $\mathrm{OO} \mathrm{aQ}$ and $\mathrm{B} 4$ from the $\mathrm{O}(\mathrm{P}) \mathrm{AZq}$ sequence, while $\mathrm{B} 8$ is a mix of $\mathrm{B} 3$ and $\mathrm{B} 4$ but also contains spent black liquor from the cooking process. E6 is the effluent from the two Po steps and E7 from the OO QQ sequence (see Table 1 for complete bleaching sequences of each process). At the time of sampling, the bleached line of mill E processed hardwood, while mill B processed softwood. The $\mathrm{pH}$-values ranged from 3.1 to 7.3 , TOC-values from $0.2-0.6 \mathrm{~g}$ TOC L $\mathrm{L}^{-1}$ while the COD TOC ${ }^{-1}$ was 2.7-3.0 (Table A.5). The methane production over time showed similar trends for all samples with a high initial methane production followed by decreasing yields compared to the inoculum controls (Figure 1F). Before methane formation took off, inhibitions were seen for B4, E6 and E7. The final yield was around 10\% of the theoretical methane potential for B3, B4, E6 and E7, while B8 gave a negative final methane yield (Figure 1F). The inhibiting effect of B8 is likely due to its content of spent black liquor. No differences in methane yields or methane formation patterns between softwood and hardwood were seen for the TCF effluents (mill B vs. E. respectively). 
Despite that the use of ECF/TCF bleaching has reduced the AOX load of KP bleaching effluents with $48-65 \%$ compared to the use of $\mathrm{Cl}_{2}$ (reviewed by [20]) we show that the acidic ECF bleaching effluents still are highly toxic to the AD-flora and that also the TCF bleaching effluents have a very low final methane yields (Figure 1F and Table A.5) possibly linked to some sort of inhibition. There is however a difference in the methane formation patterns between the ECF- and TCF-bleaching effluents (Figures 1D and 1E vs. Figure 1F).

Three of the four alkaline ECF effluents (Figure 1E) had a positive final methane yield, where the methane production followed that of the inoculum controls after day 7 . Thus, the organic matter of these effluents did not contribute to methane formation during the continuation of the incubation (Figure 1E). On the contrary the patterns of the TCF-effluents showed a decrease in methane yield over time. This indicates differences in the TOC produced in the alkaline ECF bleaching steps compared to the TCF bleaching, which is also supported by a previous study by Cates et al. [23] where it was reported that TCF effluents contain more low molecular weight compounds than ECF effluents and these compounds might have toxic effect on the AD-microflora. In addition, comparisons among effluents from different bleaching sequences have shown that composite ECF-effluents (i.e. acidic + alkaline bleaching sequences) appears to be more toxic than TCF effluents. There are also indications that bleaching effluents from softwood pulp are more toxic/less degradable than those from hardwood pulp [23-24] which is supported by the results from the ECF-bleaching effluents of this study (Fig. 1D). These previous results also fits well with ours from the acidic and composite effluents from ECF compared to the TCF effluents. However, it is important to realize that the toxicity and characteristics of all effluents are greatly dependent on the accumulation (recirculation) of COD/TOC and/or bleaching chemicals in the studied systems.

\subsection{Mechanical pulp bleaching effluents}

The TOC levels of the five TMP-bleaching effluents ranged 2.1-3.3 $\mathrm{g} \mathrm{L}^{-1}$, with COD TOC ${ }^{-1}$ of 2.9-3.5 and $\mathrm{pH}$ between 6.8 and 8.7 (Table A.6). The two samples from the hydrogen peroxide bleaching process at mill G (CTMP) showed similar methane formation patterns with final methane yields around $50 \%$ of the theoretical potential (Figure 1G). Also A41 and B7 had final yields around 50\%, while B9 had a final methane yield of 36\%. B7 and B9 are combined effluents containing both refinery and bleaching effluents while A41, G3 and G5 only contain effluents from the bleaching processes. A41, B7 and B9 all showed a slight initial inhibition compared to the inoculum controls (Figure 1G). These initial inhibitions may be due to peroxide residues and/or chelating agents from the bleaching at these mills. At the time of sampling, the process at mill $\mathrm{G}$ was producing unbleached pulp, why doses of hydrogen peroxide and chelating agents were lower, thus giving lower levels of these compounds in G3 and G5 compared to A41, B7 and B9. The lower final $\mathrm{CH}_{4}$-yield obtained from B9 than from B7 may be a result of a higher content of resin coated fibers (pers. comm. with personnel at mill B).

\subsection{Condensate effluents}

Three condensate effluents were sampled; B12, E9 and F20. The TOC concentrations ranged 0.2-3.3 $\mathrm{g} \mathrm{L}^{-1}$, while the COD $\mathrm{TOC}^{-1}$ were 3.8-4.5 and the $\mathrm{pH}$ 8.0-9.4 (Table A.7). The 
final yields obtained from E9 and F20 were $65 \%$ of the theoretical potential, while B12 yielded $118 \%$ (Figure $1 \mathrm{H})$. The effluent with the highest TOC-content $\left(3.3 \mathrm{~g} \mathrm{~L}^{-1}, \mathrm{~B} 12\right)$, initially caused an inhibition in the methane production, a clear methane production can be seen from between day 10 and 16. B12 and E9 are a foul condensate, rich in methanol, and F20 is a mix of condensate of different purity levels (A, B and C-condensates where A and B both contain about 50\% methanol). Due to the methanol content of B12, E9 and F20, the methane yields are likely overestimated, since our assumption that the TOC consists of $100 \%$ carbohydrates gives a lower theoretical maximum production of methane than methanol-rich substrates would.

\subsection{Papermaking white waters}

Four samples were taken from paper- and drying machine white waters (Table 2). Their TOC values ranged 0.1-0.5 g TOC $\mathrm{L}^{-1}$, with TOC $\mathrm{COD}^{-1}$ of 1.7-6.5 and $\mathrm{pH}$-values covering 5.4 to 8.6. The highest methane yield were obtained for A9 ( $65 \%$ of the theoretical potential) and D11 ( $\sim 55 \%$ of the theoretical potential; Figure $1 \mathrm{I})$. The TOC values of these effluents were about 0.5 and $0.2 \mathrm{~g} \mathrm{~L}^{-1}$ respectively (Table A.8). The incubation of B5 gave a low final methane yield (less than $10 \%$ of the theoretical potential) and for this effluent the methane production also decreased over time compared to the inoculum control incubations. $\mathrm{C} 1$ gave a similar methane formation pattern but more pronounced than for B5, with a maximum production of over $500 \mathrm{NmL} \mathrm{CH}_{4} \mathrm{~g}^{-1}$ added TOC after 7 days of incubation (Figure 1I). The methane formation then ceased compared to the controls, why the yield became negative from day 45. The $\mathrm{SD}$ is large for $\mathrm{C} 1$, but a yield below $10 \%$ of the theoretical potential is concluded. The reasons for the lower/negative yields of B5 and $\mathrm{C} 1$ are unknown but might be linked to additives applied in the paper making process [11]. The pattern of methane formation for B5 however resembles that of the bleaching effluents from the same mill (Figure 1F), which implies that the TOC and possibly inhibiting substances are similar in these effluents. The COD to TOC ratio of A9 is 6.5 compared to 2.7, 2.9 and 1.7 for effluents B5, C1 and D11, indicating more reduced organic compounds in A9, which might give an increased methane yield and also an underestimation of the theoretical methane potential as given in the material and methods section. The high ratio of A9 can however not be fully explained by the presence of reduced carbon compounds, indicating disturbances in the analysis of COD or TOC for this effluent.

\subsection{Neutral sulfite semi-chemical processes}

Two samples were obtained from NSSC-processes producing fluting from hardwood. Both were composite effluents of the NSSC-processes and showed high and similar methane yields $(60 \%$ of the theoretical potential; Figure $1 \mathrm{~J})$ and also similar methane formation patterns, although the streams had different TOC-concentrations $\left(1 \mathrm{~g} \mathrm{~L}^{-1}\right.$ for $\mathrm{C} 10$ and $0.2 \mathrm{~g} \mathrm{~L}^{-1}$ for D2; Table A.9). The COD to TOC ratios were 3.8 and 3.3 and the $\mathrm{pH} 7.3$ and 7.0 for $\mathrm{C} 10$ and D2, respectively. Both successful treatments and inhibition of methane production has been reported earlier for NSSC spent liquors (reviewed by Rintala and Puhakka [9]). 


\subsection{Before pre-sedimentation composite effluents}

The TOC of the seven sampled pre-sedimentation effluents ranged from 0.4-3.9 $\mathrm{g}_{\text {TOC L }}^{-1}$ with COD TOC $^{-1}$ of 2.6 to 3.7 and pH-values of 5.1-8.5 (Table A.10). The highest methane yield was obtained with material from D6 ( $55 \%$ of the theoretical potential). A12 C7 and F10 had a final methane yield corresponding to $\sim 40 \%$ of the theoretical yield (a high SD should be noted for F10), B10 and G7 around 20\% and E15 below 10\%. For B10, C7, F10 and $\mathrm{E} 15$ the total/main methane yield was obtained within 14 days of incubation, while a lagphase was observed for G7, which had the highest TOC content of the pre-sedimentation effluents (3.9 $\mathrm{g} \mathrm{L}^{-1}$; Figure $\left.1 \mathrm{~K}\right)$. D6 initially showed similar methane production rates as B10, $\mathrm{C} 7$ and E15, but while the gas-production leveled off in the later, D6 continued to produce methane at a relatively high rate up to day 34 . F10 does not include acidic bleaching effluents and C7 and D6 do not include any bleaching effluents while B10 and E15 include all bleaching wastewaters from the respective mill. As mentioned above mill G produced unbleached pulp at the sampling occasion.

The low potential of G7 might be related to the high TOC of this effluent but can also be due to differences in the composition of the fiber fraction of the CTMP mill compared to the KP mills, with higher lignin content in the CTMP fibers, thus, making them less available for digestion.

\subsection{After pre-sedimentation}

Eleven samples were taken from effluents after sedimentation. The TOC concentrations in these samples ranged $0.07-2.0 \mathrm{~g} \mathrm{~L}^{-1}$ with $\mathrm{COD} \mathrm{TOC}^{-1}$ of 2.3 to 3.9 (Table A.11). The $\mathrm{pH}$ ranged 5.5-10.0. The highest methane yield was obtained for $\mathrm{A} 13$ ( $55 \%$ of the theoretical potential) followed by G8 ( 45\%), B11, C8 and D13 ( 20\%) and C11 ( 5\%). D14, E16, F17, F15 and F16 all yielded less methane than the respective inoculum controls.

The highest yields were obtained from two of the three mechanical processes (A13 and G8; Figure 1L), which also displayed the two highest TOC values (1.2 and $2.0 \mathrm{~g} \mathrm{~L}^{-1}$, respectively; Table A.11). However, the pattern of methane formation differed between these two samples (Figure 1L). The organic matter in A13 was degraded faster, possibly related to less lignin and wood extractives in the TMP water compared to CTMP [9].

C8 and D13 do not contain bleaching effluents, while B11, C11 and D14 do, which may be the reason for the differences in methane yields between $\mathrm{C} 8$ and $\mathrm{C} 11$ and between D13 and D14. This also strengthens the earlier assumption that the acidic ECF bleaching effluents are toxic to the AD-flora.

The methane formation pattern of E16 was similar to that of E15 but with a higher initial production and a steeper decrease with time (Figure 1L vs. Figure 1K). The methane formation patterns for these effluents also resemble that of the bleaching effluents from the same mill (E6 and E7; Figure 1F) and implies that toxic/inhibiting intermediates also from the TCF-bleaching affects the yields of the effluents downstream. The reason for the inhibition of AD from effluent F15 is unknown and somewhat surprising since this effluent is downstream F10 and does not contain additional effluents. One possible explanation is that the fibers present in F10 somehow detoxified the chemicals present in the water, for example by protecting microorganisms forming colonies on the fiber. This needs however to be further 
investigated. F16 and F17 contain effluents from the resin digester house which can explain the inhibition on AD from these effluents.

Comparison between pattern of methane formation over time and final $\mathrm{CH}_{4}$-yields between effluents before and after pre-sedimentation (Figure $1 \mathrm{~K}$ and Figure 1L) shows that higher yields ( $\left.\mathrm{NmL} \mathrm{CH}_{4} \mathrm{~g}^{-1} \mathrm{TOC}\right)$ are obtained in the KP pre-sedimentation effluents than after the fibers have been removed, while the reverse relation (i.e. higher yields after removal of fibers) occurred for the effluents from the mechanical processes. The high yields of the residue fibers from kraft pulping is likely due to their relatively high cellulose content, as the main part of the lignin is removed in the process and is thus mainly found in the dissolved wastewater fraction, while in the mechanical pulp most of the lignin stays in the fibers. The results suggests that fiber sediments from KP mills carry a large methane potential that the paper mills could utilize by AD instead of dewatering and burning it at low energy gains.

\subsection{Principal component analysis}

The bi-plot of PC1 and PC2 including all sampled effluents explained $75.8 \%$ of the variance in the dataset, however B1 and B12 showed outlier behaviour (bi-plot not shown) and thus dominated PC1 and PC2 due to high COD and TOC content (Table A.1 and A.7) and high methane yield per added TOC (B12). To further investigate the dataset a PCA was therefore applied excluding B1 and B12.

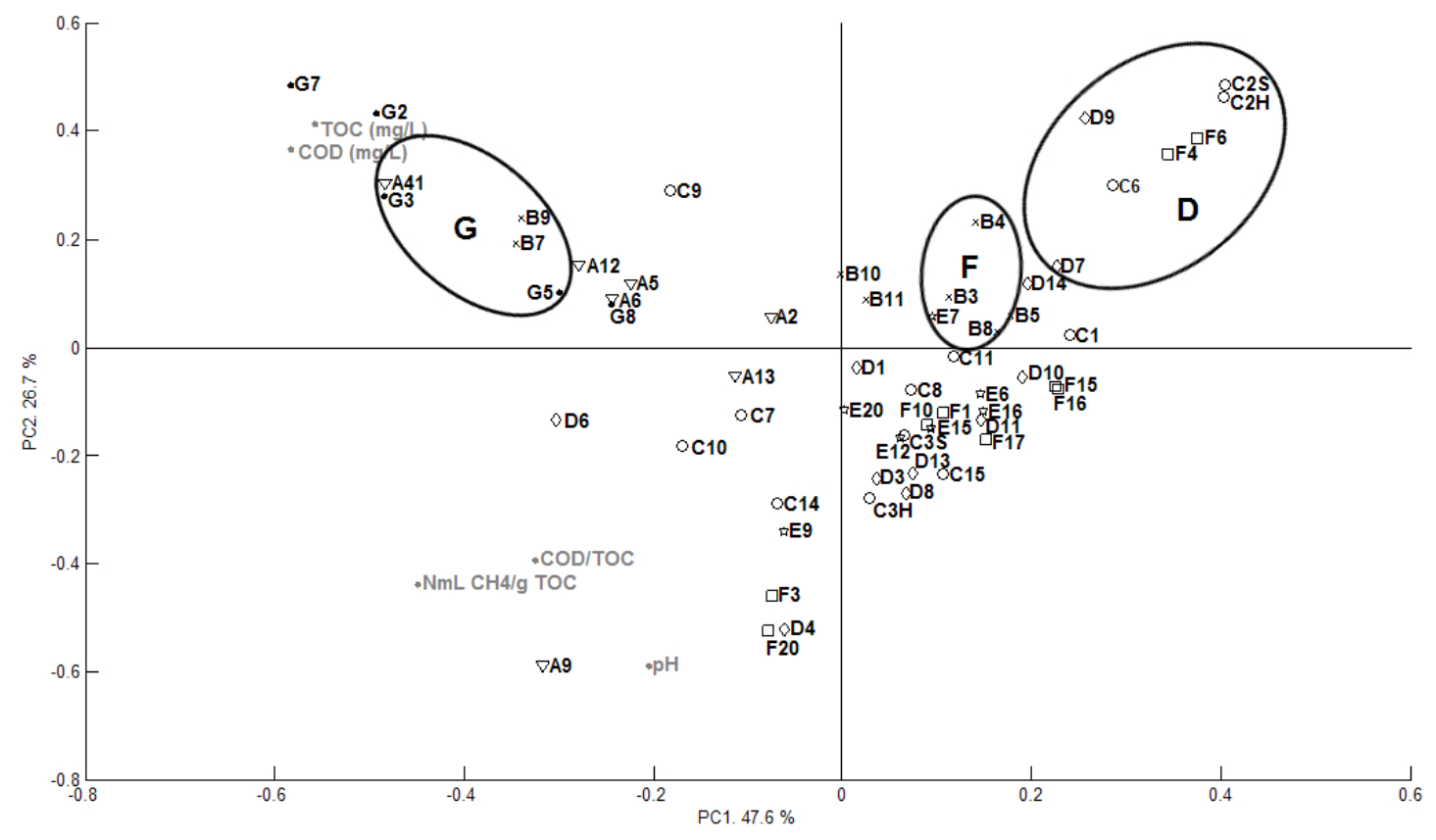

Figure 2 Bi-plot of the first two PCs from Principal component analysis of the parameters: $\mathrm{pH}$, TOC (mg L-1), COD (mg L- ${ }^{-1}$ ), COD TOC ${ }^{-1}$ and $\mathrm{NmL} \mathrm{CH}_{4} \mathrm{~g}^{-1}$ TOC for all sampled wastewaters excluding B1 and B12. The data has been centered and scaled to unit variance. Three clusters are accentuated: $D=$ effluents from the D-step in kraft ECF pulp bleaching and total effluents from kraft ECF pulp bleaching; $F=T C F$ Pulp bleaching effluents; $G=$ mechanical pulp bleaching effluents. 
By excluding B1 and B12 the explained variance decreased slightly (74.3\%). No clearly separated groups of effluents could be seen, but three clusters can be distinguished partially integrated with the remaining dataset (Figure 2). Cluster D and cluster F are found in the upper right quadrant. Cluster D includes all effluents from the D-step in kraft ECF pulp bleaching and total effluents from kraft ECF pulp bleaching. This cluster is characterized by a low methane yield and pH (Table A.4). Cluster F includes all TCF pulp bleaching effluents; the location close to the center of the bi-plot implies that this group is closer to the average effluent in this dataset. The third cluster $(G)$ is located in the upper left quadrant and includes all mechanical pulp bleaching effluents. It shall also be noted that 12 out of 14 effluents from the CTMP and TMP mills can be found in the upper left quadrant. This is mainly due to the higher COD and TOC content compared to average effluents from the kraft process.

\section{CONCLUSIONS}

- For the KP-mills, the pulping effluents D4 and F3, together with the PM effluent D11, condensate effluents B12, E9 and F20 and the composite pre-sedimentation effluent D6 gave methane yields at or above $50 \%$ of the theoretical potential.

- The acidic ECF-effluents were for the KP mills shown to be the most toxic to the AD-flora independent of if hard- or softwood was used in the production, and these effluents also affected the yield of composite downstream effluents negatively.

- The methane yields of the alkaline ECF effluents seemed to be dependent on the raw material, as hardwood effluents gave higher yields than softwood effluents.

- All TCF-bleaching effluents at the KP mills gave similar methane formation patterns, the raw material did not seem to affect the yields of these effluents.

- The fiber fraction of the KP mills holds a large, likely easily accessible, methane potential.

- The composite effluents from the two NSSC-processes was shown to be potent substrates, both gave methane yields of $60 \%$ of the theoretical potential.

- The effluents from the TMP mill (A) gave high yields with all seven sampled effluents at/or above $40 \%$ of the theoretical potential. Best yields were obtained from the PM- (A9; $\sim 65 \%$ ), the refinery- (A6; $\sim 55 \%$ ) and the outgoing presedimentation effluents (A13; 55\%).

- The three samples from the CTMP process at mill B showed potentials around $40 \%$ while three of the six effluents at mill G (CTMP) yielded 45-50\% (the bleaching effluents G3 and G5 and the composite effluent after sedimentation (G8).

Further studies are now performed on selected streams. The present focus is on fiber fractions and alkaline ECF bleaching effluents. 


\section{GLOSSARY}

$\begin{array}{ll}\text { A } & \text { Acid bleaching step } \\ \text { AD } & \text { Anaerobic digestion } \\ \text { COD } & \text { Chemical oxygen demand } \\ \text { CSTR } & \text { Completely stirred tank reactor } \\ \text { CTMP } & \text { Chemical thermo-mechanical pulp } \\ \text { D } & \text { ClO }_{2} \text {-bleaching } \\ \text { DM } & \text { Drying machine } \\ \text { E } & \text { Alkaline bleaching step } \\ \text { ECF } & \text { Elemental chlorine free } \\ \text { IC50\% } & \text { 50\% inhibiting concentration } \\ \text { KP } & \text { Kraft pulp } \\ \text { NmL } & \text { Normalized milliliter } \\ \text { NSSC } & \text { Neutral sulfite semi-chemical } \\ \text { O } & \text { Oxygen bleaching } \\ \text { P } & \text { Hydrogen peroxide bleaching } \\ \text { PM } & \text { Paper machine } \\ \text { Q } & \text { Bleaching with chelating agents } \\ \text { SD } & \text { Standard deviation } \\ \text { TCF } & \text { Total chlorine free } \\ \text { TMP } & \text { Thermo-mechanical pulp } \\ \text { TOC } & \text { Total organic carbon } \\ \text { TS } & \text { Total solids } \\ \text { UASB } & \text { Upflow anaerobic sludge blanket } \\ \text { VS } & \text { Volatile solids } \\ \text { Z } & \text { Bleaching with ozone } \\ \end{array}$

\section{ACKNOWLEDGEMENT}

The authors wish to thank the personnel at the mills for assistance during sampling and for providing information of processes and effluents. This study was funded by the Swedish Energy Agency. 


\section{REFERENCES}

[1] Krogerus M, Tennander E, Sivard A, Sammanställning av erfarenheter från hantering av slam inom skogsindustrin. 1999, Värmeforsk Rapport 666: Stockholm. p. 49.

[2] Alonso V, Martin A, Borja R, Chica A Anaerobic treatment of wastewater produced in the manufacture of cellulosic pulp from wheat straw. EnvironTechnol 1993;141145-1153

[3] Pokhrel D, Viraraghavan T Treatment of pulp and paper mill wastewater - A review. Sci Total Environ 2004;33337-58

[4] Driessen WJBM, Wasenius CO Combined anaerobic/aerobic treatment of peroxide bleached TMP mill effluent. Wat Sci Technol 1994;29381-389

[5] Dufresne R, Liard A, Blum MS Anaerobic treatment of condensates: Trial at a kraft pulp and paper mill. Water Environ Res 2001;73103-109

[6] Tielbaard M, Wilson T, Feldbaumer E, Driessen W. Full-scale anaerobic treatment experiences with pulp mill evaporator condensates. In Proceedings from TAPPI International Environmetal Conference and Exhibit; Montreal, QC; April 2002; pp 621-34.

[7] Lacorte S, Latorre A, Barceló D, Rigol A, Malmqvist A, Welander T Organic compounds in papermill process waters and effluents. TrAC - Trends in Analytical Chem 2003;22725-737

[8] Sierra-Alvarez R, Field JA, Kortekaas S, Lettinga G Overview of the anaerobic toxicity caused by organic forest industry wastewater pollutants. Wa Sci Technol 1994;29353-363

[9] Rintala JA, Puhakka JA Anaerobic treatment in pulp- and paper-mill waste management: A review. Biores Technol 1994;471-18

[10] Buzzini AP, Pires EC Evaluation of a upflow anaerobic sludge blanket reactor with partial recirculation of effluent used to treat wastewaters from pulp and paper plants. Biores Technol 2007;981838-1848

[11] Latorre A, Malmqvist A, Lacorte S, Welander T, Barceló D Evaluation of the treatment efficiencies of paper mill whitewaters in terms of organic composition and toxicity. Environ Poll 2007;147648-655

[12] Poggi-Varaldo HM, C. E-V, Fernández-Villagómez G, Esparza-Garcia F. Pretreatment of black liquor spills effluent. in 51st Purdue University Industrial Waste Conference proceedings. 1996 pp 651-61

[13] Vidal G, Diez MC Methanogenic toxicity and continuous anaerobic treatment of wood processing effluents. J Environ Manage 2005;74317-325

[14] Swedish Standard 12176, Characterization of sludge - Determination of $\mathrm{pH}$-value. Swedish Standard Institute 1998.

[15] Karlsson A, Ejlertsson J, Nezirevic D, Svensson BH Degradation of phenol under meso- and thermophilic, anaerobic conditions. Anaerobe 1999;525-35

[16] Kortekaas S, Wijngaarde RR, Klomp J-W, Lettinga G, Field JA Anaerobic treatment of hemp thermomechanical pulping wastewater. Water Res 1998;323362-3370

[17] Sierra-Alvarez R The continuous anaerob treatment of pulping wastewaters. J. Ferment. Bioeng. 1990;70119-127

[18] Yang MI, Edwards EA, Allan DG Anaerobic treatment and biogas production potential of selected in-mill streams. Wat Sci Technol 2010;622427-2434

[19] Janga KK, Hägg M-B, Moe ST Influence of acid concentration, temperature, and time on the decrystallization in two-stage concentrated sulfuric acid hydrolysis of pinewood and aspenwood: a statical approach. BioResources 2012;7391-411

[20] Kostamo A, Holmbom B, Kukkonen JVK Fate of wood extractives in wastewater treatment plants at kraft pulp mills and mechanical pulp mills. Water Res 2004;38972-982

[21] Ek M, Gellerstedt G, Henriksson G, eds. Wood chemistry and wood technology. 1st ed. Vol. 1. 2009, de Gruyter: Berlin.

[22] Calvo L, Gilarranz MA, Casas JA, Mohedano AF, Rodríguez JJ Detoxification of Kraft pulp ECF bleaching effluents by catalytic hydrotreatment. Water Res 2007;41915-923 
[23] Cates DH, Eggert C, Yang JL, Eriksson K-EL Comparison of effluents from TCF and ECF bleaching of kraft pulps. Tappi Journal 1995;7893-98

[24] Vidal G, Becerra J, Hernández V, Decap J, Xavier CR Anaerobic Biodegradation of Sterols Contained in Kraft Mill Effluents. J Biosci Bioeng 2007;104476-480 
Appendix A pH, TOC, COD and COD TOC ${ }^{-1}$ of all samples. TOC and COD values are means of triplicates with maximum standard deviation (SD) of 5 and $1 \%$ respectively. $\mathrm{CH}_{4^{-}}$ yields are means of triplicates $\pm S D$. $h w=$ hardwood, $s w=$ softwood; unb=unbleached, rec $\mathrm{p}=$ recycled paper

\begin{tabular}{|c|c|c|c|c|c|c|}
\hline \multicolumn{7}{|c|}{ Table A.1, Wood room effluents } \\
\hline mill & $\begin{array}{c}\text { raw } \\
\text { material }\end{array}$ & $\mathrm{pH}$ & $\begin{array}{c}\text { TOC } \\
\left(\mathrm{mg} \mathrm{L}^{-1}\right)\end{array}$ & $\begin{array}{c}\text { COD } \\
\left(\mathrm{mg} \mathrm{L}^{-1}\right)\end{array}$ & $\begin{array}{l}\text { COD } \\
\text { TOC }^{-1}\end{array}$ & $\begin{array}{c}\mathrm{CH}_{4} \\
\left(\mathrm{NmL} \mathrm{g}{ }^{-1} \mathrm{TOC}\right)\end{array}$ \\
\hline$\overline{A 2}$ & sw (spruce) & 4.8 & 1030 & 3620 & 3.5 & $370 \pm 15$ \\
\hline $\mathrm{B} 1$ & SW & 4.6 & 7730 & 29170 & 3.8 & $-24 \pm 0$ \\
\hline C9 & sw & 5.0 & 1950 & 6180 & 3.2 & $230 \pm 41$ \\
\hline $\mathrm{D} 1$ & $\mathrm{sw}+\mathrm{hw}$ & 6.1 & 660 & 2190 & 3.3 & $270 \pm 28$ \\
\hline $\mathrm{F} 1$ & sw & 6.6 & 220 & 730 & 3.3 & $200 \pm 68$ \\
\hline mill & $\begin{array}{c}\text { raw } \\
\text { material }\end{array}$ & $\mathrm{pH}$ & $\begin{array}{c}\text { TOC } \\
\left(\mathrm{mg} \mathrm{L}^{-1}\right)\end{array}$ & $\begin{array}{c}\mathrm{COD} \\
\left(\mathrm{mg} \mathrm{L}^{-1}\right)\end{array}$ & $\begin{array}{l}\text { COD } \\
\text { TOC }^{-1}\end{array}$ & $\begin{array}{c}\mathrm{CH}_{4} \\
\left(\mathrm{NmL} \mathrm{g}^{-1} \mathrm{TOC}\right)\end{array}$ \\
\hline A5 & sw (spruce) & 5.2 & 1620 & 5960 & 3.7 & $430 \pm 43$ \\
\hline A6 & sw & 4.4 & 1510 & 6030 & 4.0 & $510 \pm 53$ \\
\hline $\mathrm{G} 2$ & sw (unb) & 8.5 & 2940 & 10370 & 3.5 & $-60 \pm 0$ \\
\hline \multicolumn{7}{|c|}{ Table A.3, Kraft cooking effluents } \\
\hline mill & $\begin{array}{c}\text { raw } \\
\text { material }\end{array}$ & $\mathrm{pH}$ & $\begin{array}{c}\text { TOC } \\
\left(\mathrm{mg} \mathrm{L}^{-1}\right)\end{array}$ & $\begin{array}{c}\text { COD } \\
\left(\mathrm{mg} \mathrm{L}^{-1}\right)\end{array}$ & $\begin{array}{l}\text { COD } \\
\text { TOC }^{-1}\end{array}$ & $\begin{array}{c}\mathrm{CH}_{4} \\
\left(\mathrm{NmL} \mathrm{g}{ }^{-1} \text { TOC) }\right.\end{array}$ \\
\hline C14 & sw & 11.6 & 840 & 2480 & 2.9 & $350 \pm 34$ \\
\hline $\mathrm{C} 15$ & SW & 9.6 & 210 & 650 & 3.1 & $86 \pm 170$ \\
\hline D4 & SW & 10.0 & 160 & 620 & 3.9 & $660 \pm 30$ \\
\hline E12 & hw & 8.9 & 460 & 1430 & 3.1 & $110 \pm 10$ \\
\hline E20 & hw & 9.1 & 780 & 2440 & 3.1 & $120 \pm 5.2$ \\
\hline F3 & sw (pine) & 10.0 & 330 & 1350 & 4.1 & $450 \pm 26$ \\
\hline \multicolumn{7}{|c|}{ Table A.4; ECF bleaching process effluents at kraft mills } \\
\hline mill & $\begin{array}{c}\text { raw } \\
\text { material }\end{array}$ & $\mathrm{pH}$ & $\begin{array}{c}\text { TOC } \\
\left(\mathrm{mg} \mathrm{L}^{-1}\right)\end{array}$ & $\begin{array}{c}\mathrm{COD} \\
\left(\mathrm{mg} \mathrm{L}^{-1}\right)\end{array}$ & $\begin{array}{l}\text { COD } \\
\text { TOC }^{-1}\end{array}$ & $\begin{array}{c}\mathrm{CH}_{4} \\
\left(\mathrm{NmL} \mathrm{g}{ }^{-1} \mathrm{TOC}\right)\end{array}$ \\
\hline C2S & sw & 2.5 & 270 & 630 & 2.3 & $-690 \pm 13$ \\
\hline $\mathrm{C} 2 \mathrm{H}$ & hw & 2.4 & 210 & 480 & 2.3 & $-610 \pm 10$ \\
\hline D7 & hw & 3.6 & 170 & 400 & 2.4 & $200 \pm 140$ \\
\hline D9 & SW & 3.2 & 730 & 1700 & 2.3 & $-350 \pm 11$ \\
\hline $\mathrm{F} 4$ & sw (pine) & 2.8 & 210 & 540 & 2.6 & $-460 \pm 24$ \\
\hline C3S & SW & 10.8 & 640 & 1550 & 2.4 & $130 \pm 51$ \\
\hline $\mathrm{C} 3 \mathrm{H}$ & hw & 11.6 & 560 & 1330 & 2.4 & $330 \pm 22$ \\
\hline D8 & hw & 10.8 & 370 & 880 & 2.4 & $360 \pm 16$ \\
\hline D10 & sw & 11.5 & 540 & 1230 & 2.3 & $-400 \pm 13$ \\
\hline $\mathrm{C} 6$ & sw & 5.0 & 470 & 1000 & 2.1 & $-310 \pm 16$ \\
\hline F6 & sw (pine) & 2.9 & 180 & 450 & 2.5 & $-570 \pm 25$ \\
\hline
\end{tabular}




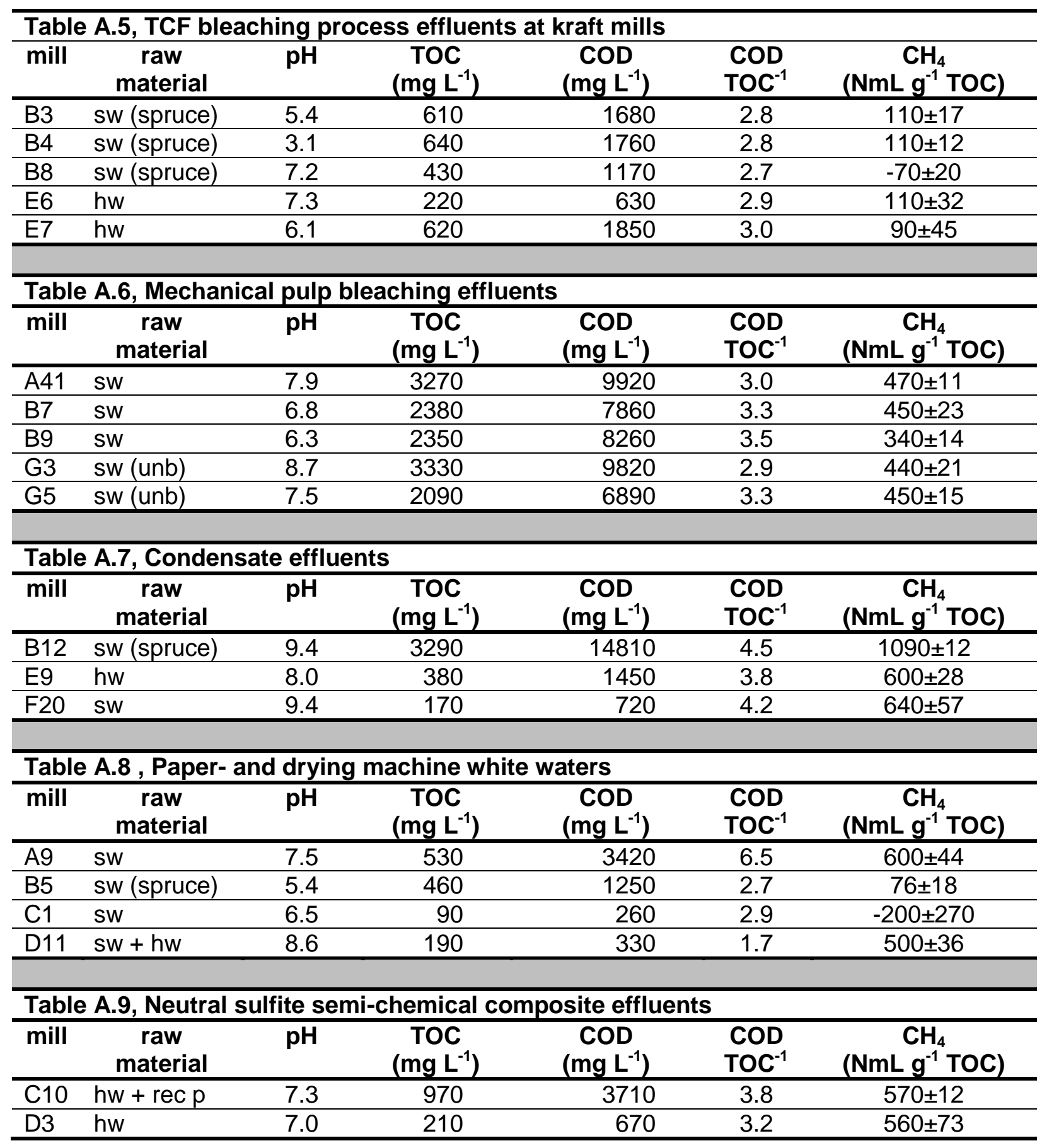




\begin{tabular}{|c|c|c|c|c|c|c|}
\hline mill & $\begin{array}{c}\text { raw } \\
\text { material }\end{array}$ & $\mathrm{pH}$ & $\begin{array}{c}\text { TOC } \\
\left(\mathrm{mg} \mathrm{L}^{-1}\right)\end{array}$ & $\begin{array}{c}\text { COD } \\
\left(\mathrm{mg} \mathrm{L}^{-1}\right)\end{array}$ & $\begin{array}{l}\text { COD } \\
\text { TOC }^{-1}\end{array}$ & $\begin{array}{c}\mathrm{CH}_{4} \\
\left(\mathrm{NmL} \mathrm{g}{ }^{-1} \mathrm{TOC}\right)\end{array}$ \\
\hline$\overline{\mathrm{A} 12}$ & sw & 7.0 & 2110 & 6870 & 3.3 & $370 \pm 16$ \\
\hline B10 & sw (spruce) & 5.1 & 1030 & 3260 & 3.2 & $160 \pm 19$ \\
\hline $\mathrm{C} 7$ & sw & 7.5 & 930 & 3420 & 3.7 & $360 \pm 15$ \\
\hline D6 & $\mathrm{sw}+\mathrm{hw}$ & 10.2 & 1760 & 6070 & 3.4 & $510 \pm 19$ \\
\hline E15 & hw & 8.1 & 370 & 1230 & 3.3 & $66 \pm 12$ \\
\hline $\mathrm{F} 10$ & sw (pine) & 8.0 & 350 & 910 & 2.6 & $360 \pm 310$ \\
\hline G7 & sw & 8.0 & 3920 & 12660 & 3.2 & $210 \pm 5.4$ \\
\hline mill & $\begin{array}{c}\text { raw } \\
\text { material }\end{array}$ & $\mathrm{pH}$ & $\begin{array}{c}\text { TOC } \\
\left(\mathrm{mg} \mathrm{L}^{-1}\right)\end{array}$ & $\begin{array}{c}\mathrm{COD} \\
\left(\mathrm{mg} \mathrm{L}^{-1}\right)\end{array}$ & $\begin{array}{l}\text { COD } \\
\text { TOC }^{-1}\end{array}$ & $\begin{array}{c}\mathrm{CH}_{4} \\
\left(\mathrm{NmL} \mathrm{g}{ }^{-1} \mathrm{TOC}\right)\end{array}$ \\
\hline$\overline{\mathrm{A} 13}$ & sw & 7.3 & 1160 & 3570 & 3.1 & $510 \pm 18$ \\
\hline B11 & sw (spruce) & 5.5 & 880 & 2730 & 3.1 & $170 \pm 11$ \\
\hline $\mathrm{C} 8$ & sw & 7.7 & 520 & 1550 & 3.0 & $160 \pm 21$ \\
\hline C11 & sw & 7.1 & 470 & 1360 & 2.9 & $40 \pm 20$ \\
\hline D13 & $s w+h w$ & 10.0 & 360 & 1000 & 2.8 & $200 \pm 12$ \\
\hline D14 & $\mathrm{sw}+\mathrm{hw}$ & 6.4 & 470 & 1070 & 2.3 & $-27 \pm 34$ \\
\hline E16 & hw & 7.5 & 170 & 560 & 3.3 & $-31 \pm 10$ \\
\hline F15 & sw (pine) & 8.1 & 76 & 250 & 3.3 & $-370 \pm 73$ \\
\hline F16 & sw (pine) & 8.0 & 68 & 260 & 3.8 & $-540 \pm 98$ \\
\hline F17 & sw (pine) & 7.5 & 71 & 280 & 3.9 & $-170 \pm 32$ \\
\hline G8 & SW & 7.1 & 1960 & 6510 & 3.3 & $430 \pm 5.9$ \\
\hline
\end{tabular}

